\title{
EFFECT OF SOIL pH AND ORGANIC MATTER ON LABILE ALUMJNIUM IN SOILS UNDER PERMANENT GRASS
}

\author{
F. CABRERA' AND O. TALIBUDEEN \\ (Rothamsted Experimental Station, Harpenden, Herts.)
}

\section{Summary}

The rates of extraction of $\mathrm{Na}, \mathrm{K}, \mathrm{Mg}, \mathrm{Ca}$, and $\mathrm{Al}$ with $1 \mathrm{M} \mathrm{NH} \mathrm{NO}_{3}$ from the mineraland organic-rich layers of some Park Grass (Rothamsted) soils were measured at the pH of the soil. Below pH 3.7 exchangeable $\mathrm{Al}$, derived from the kinetics curve, increases with decreasing soil $\mathrm{pH}$ and is less in the organic-rich layer. The sum of the basic exchangeable cations, $\Sigma(\mathrm{Na}+\mathrm{K}+\mathrm{Mg}+\mathrm{Ca})$, increases with increasing soil $\mathrm{pH}$ and is more in the organic-rich layer.

The extraction of exchangeable Al obeys first order kinetics, the rate constant being similar for all the soils (mean value $36 \pm 7 \times 10^{-6}\left[\mathrm{~s}^{-1}\right.$ ), which implies that exchangeable $\mathrm{Al}$ is released from surfaces with similar properties for the adsorption of $\mathrm{Al}$, and that the rate is not affected by soil $\mathrm{pH}$ and organic matter. The rate of extraction of non-exchangeable $\mathrm{Al}$ is the same in the mineral-and organic-rich layers of each soil, and is maximal at about pH 3.7 , decreasing sharply at more and less acid $\mathrm{pH}$ values.

\section{Introduction}

THE association of large amounts of $\mathrm{Al}$, non-exchangeable to $1 \mathrm{M} \mathrm{NH}_{4} \mathrm{Cl}$ and $1 \mathrm{M} \mathrm{KCl}$, with organic matter has been observed by several workers. McLean, Reicosky, and Lakshmanan (1965) found that the cation-exchange capacity $(\mathrm{KCl}-\mathrm{CEC})$, determined by leaching or centrifugal extraction of several acid soils with unbuffered $1 \mathrm{M} \mathrm{KCl}$ solution, increased with liming, particularly when they contained much organic matter. Destruction of organic matter decreased the ' $\mathrm{KCl}-\mathrm{CEC}$ ' only when the soil had been limed, and the amount of the decrease was proportional to the organic matter content. Pionke and Corey (1967) found that 'non-exchangeable acidic' $\mathrm{Al}$ (the difference between $\mathrm{Al}$ extracted with $1 \mathrm{M} \mathrm{NH}_{4} \mathrm{OAc}, \mathrm{pH} 4.8$, and neutral $\mathrm{M} \mathrm{KCl}$ ) correlated significantly with $\mathrm{pH}$, organic matter and clay content, the correlation with organic matter being most significant, thus implying the existence of Al-organic matter complexes in soils. Reeve and Sumner (1971) obtained similar correlations for Al and organic matter in surface soils but not in subsoils.

Exchangeable $\mathrm{Al}$ is less in surface than in subsurface soils from Virginia (Coleman and Thomas, 1967) possibly because of differences in their organic matter contents. Thomas (1975) found that, from soil treated with different amounts of $\mathrm{HNO}_{3}, \mathrm{Al}$ extracted by $1 \mathrm{M} \mathrm{KCl}$ was less as organic matter content increased at any given $\mathrm{pH}$ level.

\footnotetext{
'Permanent address: Centro de ldafologia y Biologia Aplicada del Cuarto, C.S.L.C., Sevilla, Spain.
}

Journal of Soil Science, 1977, 28, 259-270. 
These observations explain why acid soils containing much organic matter give low Al concentrations in the soil solution and produce good yields of corn and soybeans (Evans and Kamprath, 1970). Similarly Silva Rodriguez and Schaefer (1971) observed in the Nadi soils of Chile (volcanic ash soils) that high $\mathrm{Al}$ content is not harmful to natural vegetation because of organic matter accumulation, and that fulvic acid in such soils chelated about $300 \mathrm{mg}$ of $\mathrm{Al}$ per $\mathrm{g}$ of $\mathrm{C}(0.133$ atoms $\mathrm{Al} /$ atom $\mathrm{C} \equiv$ approximately 8 atoms $\mathrm{C} /$ atom $\mathrm{Al}$ ).

Recently organic compounds have been used to prevent the dissolution of $\mathrm{Al}$ in acid soils instead of liming them. Hoyt and Turner (1975) reported that adding alfalfameal, sucrose, and peat moss to very acid soils ( $\mathrm{pH} 4$ to 5.5 ), decreased toxic quantities of exchangeable AI, especially with alfalfameal. This was attributed primarily to the complexing of exchangeable $\mathrm{Al}$ by organic matter.

In our work, Al-organic matter relationships in acid surface and subsurface soils of the Park Grass experiment at Rothamsted were examined using the method of extracting exchangeable Al devised earlier by Sivasubramaniam and Talibudeen (1972) in which the kinetics of $\mathrm{Al}$ extraction from the soil were analysed to differentiate between exchangeable and non-exchangeable $\mathrm{Al}$. Organic matter $\mathrm{Ca}$ and $\mathrm{Mg}$ relationships and the possible interrelationships of the basic cations with $\mathrm{Al}$ through soil organic matter were also studied.

\section{Materials and methods}

Soils

Soils from the Park Grass experiment were selected (Table 1) which after continuous manuring since 1856 have attained stable $\mathrm{pH}$ values. The organic-rich $(0$ to $7.6 \mathrm{~cm})$ and mineral-rich $(7.6$ to $22.9 \mathrm{~cm})$ layers were sampled from the acid section of the plots, taking $1.27 \mathrm{~cm}$ cores from about 25 evenly spaced points on each plot.

The soil samples were air-dried and the coarser fractions ground in stages to $<60$ mesh in a ball mill thus minimising the effect of ball-milling on the finer fractions. Soil $\mathrm{pH}$ values were measured in $1 \mathrm{M} \mathrm{KCl}$ at a 1:2.5 ratio. Organic carbon was determined by the Walkley-Black method using a recovery factor of 1.3 .

\section{Extraction of $\mathrm{Al}, \mathrm{Na}, \mathrm{K}, \mathrm{Mg}$, and $\mathrm{Ca}$}

Aluminium and other more basic cations were extracted by leaching $1 \mathrm{~g}$ soil on a porosity 1 sintered glass crucible with $1 \mathrm{M} \mathrm{NH}_{4} \mathrm{NO}_{3}$, adjusted to the $\mathrm{pH}$ of each soil, for $48 \mathrm{~h}$ at approximately $5 \mathrm{ml} \mathrm{h}^{-1}$ using peristaltic pumps and a modifed LKB fraction collector. Up to three samples were thus examined simultaneously. Each soil was extracted in quadrupicate. Sivasubramaniam and Talibudeen (1972), using acid soils from long-term experiments of the Tea Research Institute, Sri Lanka, had established that the soil and $1 \mathrm{M} \mathrm{NH}_{4} \mathrm{Cl}$ 
TABLE 1

Description of soils

\begin{tabular}{|c|c|c|c|}
\hline Soils & Treatment & $\begin{array}{l}p H \text { in } \\
1 M K C l \\
(1: 2.5)\end{array}$ & $\begin{array}{l}\% C \\
\text { (Walkley-Black) }\end{array}$ \\
\hline $3 \mathrm{U} / \mathrm{O}$ & Nil & 4.24 & 5.25 \\
\hline $2+3 U$ & Nil & 4.23 & 2.37 \\
\hline $7 \mathrm{U} / \mathrm{O}$ & PKNaMg & 3.78 & 3.78 \\
\hline $7 \mathrm{U}$ & PKNaMg & 3.90 & 1.95 \\
\hline $8 \mathrm{U} / 0$ & $\mathrm{P} \mathrm{NaMg}$ & 4.08 & 3.67 \\
\hline $8 \mathrm{U}$ & P NaMg & 4.18 & 2.02 \\
\hline $11 \mathrm{U} / \mathrm{O}$ & $\mathrm{N}_{3} \mathrm{PKNaMg}$ & 2.88 & 11.02 \\
\hline $11 \mathrm{U}$ & $\mathrm{N}_{3} \mathrm{PKNaMg}$ & 2.98 & 2.95 \\
\hline $11 \mathrm{~L} / O$ & $\mathrm{~N}_{3}$ PKNaMg & 3.54 & 9.30 \\
\hline $11 L$ & $\mathrm{~N}_{3} \mathrm{PKNaMg}$ & 3.38 & 3.20 \\
\hline $14 \mathrm{U} / \mathrm{O}$ & $\mathrm{N}_{2} * \mathrm{PKNaMg}$ & 5.05 & 4.19 \\
\hline $14 U$ & $\mathrm{~N}_{2} * \mathrm{PKNaMg}$ & 5.02 & 2.02 \\
\hline $15 \mathrm{U} / \mathrm{O}$ & PKNaMg & 3.87 & 3.58 \\
\hline $15 \mathrm{U}$ & PKNaMg & 3.97 & 2.12 \\
\hline
\end{tabular}

$\mathrm{U}=$ unlimed $\mathrm{L}=$ limed $; \mathrm{O}=$ organic-rich layer

${ }^{1}$ For details of manuring see Warren and Johnston (1964)

* $\mathrm{N}$ as $\mathrm{NaNO}_{3}$.

solution were in equilibrium when the leaching rate was between 5 and $8 \mathrm{ml} \mathrm{h}^{-1}$. Fractions of leachate were collected at $3 \mathrm{~h}$ intervals up to $48 \mathrm{~h}$. The cumulative $\mathrm{Al}$ extracted, plotted against time, became approximately linear after $24 \mathrm{~h}$. Exchangeable $\mathrm{Al}, \mathrm{Al}_{\mathrm{x}}$, was obtained by extrapolating the linear part of the curve to 'zero time' (Sivasubramaniam and Talibudeen, 1972).

This relationship represents two simultaneous processes, the extraction of exchangeable $\mathrm{Al}, \mathrm{Al}_{\mathrm{x}}$, and non-exchangeable $\mathrm{Al}, \mathrm{Al}_{\mathrm{n} x}$. The rate of extraction of $A l_{n x}$ is constant, represented by a linear relationship. The extraction of $\mathrm{Al}_{\mathrm{x}}$ is a first order process, the rate being proportional to the amount of $\mathrm{Al}_{\mathrm{x}}$ on exchange sites at any time (Sivasubramaniam and Talibudeen, 1972).

The effluent $\mathrm{pH}$ was always greater than the influent $\mathrm{pH}$ because the hydrolysed forms of adsorbed $\mathrm{Al}$ ions are more basic than those in solution (Lim and Talibudeen, 1975; Pyman, Posner, and Talibudeen, 1976). However, the effluent pH decreased gradually to a constant value when the extraction rate became constant (Fig. 1).

The amounts of $\mathrm{Na}, \mathrm{K}, \mathrm{Mg}$, and $\mathrm{Ca}$ extracted in the first fraction were taken as exchangeable basic cations because the amounts extracted later were negligible.

\section{Analytical}

Aluminium in the leachate was determined by the Aluminon method (Chenery, 1948), Ca (by emission, with 500 parts $10^{-6}$ La and radiation buffer added), $\mathrm{Mg}$ (by atomic absorption, with 500 parts 


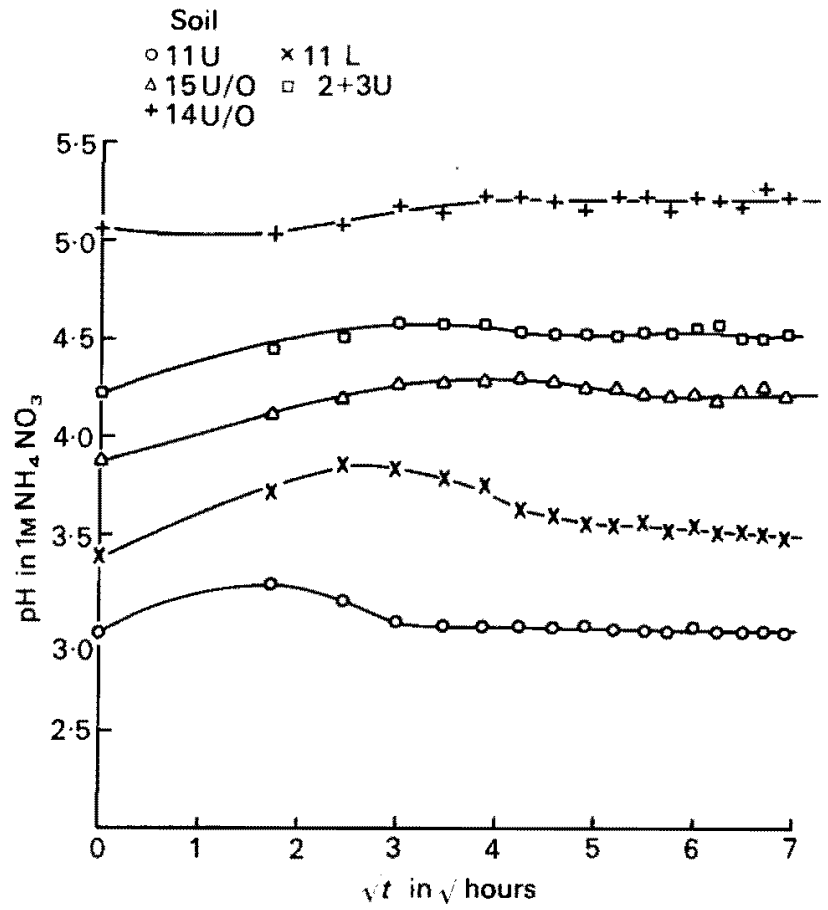

FIG. 1. Progressive change of $1 \mathrm{M} \mathrm{NH} \mathrm{NH}_{4} \mathrm{NO}_{3}$ leachate $\mathrm{pH}$ for five Park Grass soils.

$10^{-6} \mathrm{Sr}$ ), $\mathrm{Na}$ (by emission, with 25 parts $10^{-6} \mathrm{Li}$ ) on a Unicam flame photometer SP900A, and K (by emission) on an EEL flame photometer.

Standard solutions for all calibrations were prepared in $1 \mathrm{M} \mathrm{NH} \mathrm{NHO}_{3}$.

\section{Results and discussion}

Exchangeable $A l\left(A l_{x}\right)$

Plotting $\mathrm{Al}_{\mathrm{x}}$ (Table 2) against soil $\mathrm{pH}$ for the organic-rich and mineral-rich layers gives curves of similar shape, $\mathrm{Al}_{\mathbf{x}}$ values increasing with decreasing $\mathrm{pH}$. However, at soil $\mathrm{pHs}<3.7 \mathrm{Al}_{\mathrm{x}}$ increases more with the mineral-rich soils than with the organic-rich soils. Above pH 3.7 the curves for both sets of soils are indistinguishable $(P=0.05$, Fig. 2) tending to zero as the $\mathrm{pH}$ increases. This gradual decrease above $\mathrm{pH} 3.7$ is caused by more basic cations, expecially $\mathrm{Ca}$, occupying exchange sites increasingly, and also by the progressive loss of soluble $\mathrm{Al}$ to form $\mathrm{Al}_{2} \mathrm{O}_{3} \cdot \mathrm{nH}_{2} \mathrm{O}$ (gibbsite $\mathrm{p} k_{\mathrm{sp}}=33$ ). Because the $\mathrm{pH}$ and texture (mineralogy and particles size distribution) of the surface- and subsurface-soil in each comparison are similar, their organic matter contents must account for the differences in the $\mathrm{Al}_{\mathrm{x}}: \mathrm{pH}$ curves.

Organic matter complexes $\mathrm{Al}$ ions in several ways, forming mono- or multi-dentate chelates, depending on the nature and distribution of 


\section{TABLE 2}

Extraction of $\mathrm{Al}$ with $1 \mathrm{M} \mathrm{NH}_{4} \mathrm{NO}_{3}$; exchangeable $\mathrm{Al}\left(\mathrm{Al} l_{x}\right)$, and rates of extraction of non-exchangeable $A l\left(\mathrm{~d}\left(A l_{n x}\right) / \mathrm{dt}\right)$.

\begin{tabular}{|c|c|c|}
\hline Soil & $\begin{array}{l}A l_{x} \\
\left(m e g^{-1}\right)\end{array}$ & $\begin{array}{l}\mathrm{d}\left(A l_{n x}\right) / \mathrm{dt} \times 10^{6} \\
\left(m e k g^{-1} s^{-1}\right)\end{array}$ \\
\hline $3 \mathrm{U} / \mathrm{O}$ & $4.8 \pm 0.4$ & $51.9 \pm 1.7$ \\
\hline $2+3 U$ & $2.4 \pm 0.8$ & $47.5 \pm 1.1$ \\
\hline $7 \mathrm{U} / \mathrm{O}$ & $15.8 \pm 0.8$ & $141.9 \pm 21.1$ \\
\hline $7 \mathrm{U}^{\prime}$ & $14.8 \pm 2.3$ & $155.0 \pm 21.1$ \\
\hline $8 \mathrm{U} / \mathrm{O}$ & $8.9 \pm 0.8$ & $78.1 \pm 7.5$ \\
\hline $8 \mathrm{U}$ & $6.7 \pm 1.3$ & $53.9 \pm 6.1$ \\
\hline $11 \mathrm{U} / \mathrm{O}$ & $45.8 \pm 4.2$ & $85.6 \pm 18.1$ \\
\hline 110 & $82.7 \pm 1.7$ & $73.3 \pm 9.2$ \\
\hline $11 L / 0$ & $22.6 \pm 2.5$ & $215.6 \pm 46.7$ \\
\hline $11 \mathrm{~L}$ & $69.9 \pm 2.6$ & $148.6 \pm 7.2$ \\
\hline $14 U / 0$ & $3.8 \pm 0.9$ & $15.6 \pm 3.1$ \\
\hline $14 U$ & $1.5 \pm 0.2$ & $19.2 \pm 0.8$ \\
\hline $15 \mathrm{U} / \mathrm{O}$ & $21.4 \pm 1.6$ & $182.8 \pm 21.9$ \\
\hline $15 \mathrm{U}$ & $17.7 \pm 1.1$ & $138.1 \pm 11.4$ \\
\hline
\end{tabular}

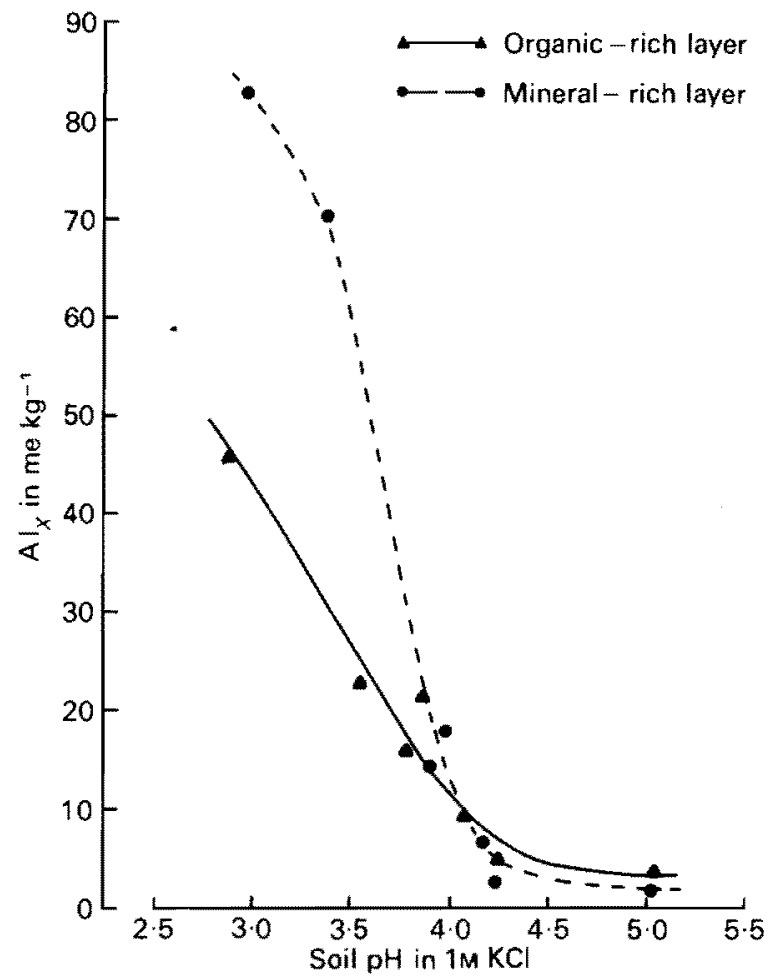

FIG. 2. The effect of soil $\mathrm{pH}$ on exchangeable $\mathrm{Al}\left(\mathrm{Al}_{\mathrm{x}}\right)$ in $1 \mathrm{M} \mathrm{NH}_{4} \mathrm{NO}_{3}$ in 'organic'and 'mineral'-rich layers. 




FIG. 3. The effect of soil $\mathrm{pH}$ on the atom ratio $\mathrm{Al}_{\mathrm{x}} /$ soil organic $\mathrm{C}$ in 'organic'-and 'mineral'-rich layers.

chelating groups on organic matter surfaces. In general, $\mathrm{Al}_{\mathbf{x}}$ can be displaced from mono-dentate complexes by solutions of $\mathrm{NH}_{4}^{+}$salts with strongly acidic anions, whereas non-exchangeable $\mathrm{Al}_{\mathrm{nx}}$ in multi-dentate chelation can be displaced only by $\mathrm{NH}_{4}^{+}$salts with stronger chelating organic anions. Thus, $\mathrm{Al}_{\mathbf{x}}$ determined in this way and displaced from mineral and organic surfaces by $1 \mathrm{M} \mathrm{NH}_{4} \mathrm{NO}_{3}$ accounts for the $\mathrm{Al}_{\mathrm{x}}$ of the soil.

From such results, it is not possible to derive separate values for surface densities of negative charge on the mineral and organic parts of the soil. One can only say that the much smaller $\mathrm{Al}_{\mathrm{x}}$ values for the organic-rich layer denote that most of the $\mathrm{Al}$ dissolved by soil acidity is immobilised by increased multi-dentate links in the organic-rich layer and cannot be released by $1 \mathrm{M} \quad \mathrm{NH}_{4} \mathrm{NO}_{3}$. Sivasubramaniam and Talibudeen (1972) showed earlier that $1 \mathrm{M} \mathrm{NH} \mathrm{NH}_{4} \mathrm{OAc}$ released $\mathrm{Al}$ ions that could not be released by $1 \mathrm{M} \mathrm{NH} \mathrm{NH}_{4} \mathrm{Cl}$ from soils containing similar amounts of organic carbon.

If exchangeable $\mathrm{Al}$ is related to total organic carbon, the atom ratio $\mathrm{Al}_{\mathbf{x}} / \mathrm{C}$ must reflect the Al-binding properties of the organic matter in the soil. Figure 3 shows that this ratio below $\mathrm{pH} 4.1$ is approximately 
constant $\left(1.53 \times 10^{-3} \pm 0.27 \times 10^{-3}\right)$ for the organic-rich layer, but increases sharply with decreasing $\mathrm{pH}$ for the mineral-rich layer. The ratio corresponds to $650 \mathrm{C}$ atoms per $\mathrm{Al}$ atom and, when compared with the $8 \mathrm{C}$ atoms per $\mathrm{Al}$ atom for fulvic acid (Silva Rodriguez and Schaefer, 1971), suggests that only about one per cent of the carbon in these soils is similar in reactivity to fulvic acid. The organic-rich surface layer in these soils accumulates fresh plant residues each year but the mineral-rich layer only receives highly decomposed skeletal organic residues.

Non-exchangeable $A l\left(A l_{n x}\right)$

Non-exchangeable $\mathrm{Al}$ extracted in $48 \mathrm{~h}$ with $1 \mathrm{M} \mathrm{NH}_{4} \mathrm{NO}_{3}$, is the difference between the total $\mathrm{Al}$ extracted in $48 \mathrm{~h}$ and $\mathrm{Al}_{\mathrm{x}}$. It expresses the constant rate of extraction of $\mathrm{Al}_{\mathrm{n} x}$ and will be discussed later.

Exchangeable $\mathrm{Na}, \mathrm{K}, \mathrm{Mg}$, and $\mathrm{Ca}$

The sum of the basic cations extracted by $1 \mathrm{M} \mathrm{NH} \mathrm{NH}_{4} \mathrm{NO}_{3}$ from the soils increases with increasing $\mathrm{pH}$, reflecting the decrease in $\mathrm{Al}_{\mathrm{x}}$. In all soils this sum is greater for the organic-rich than for the mineral-rich layer of the soil (Fig. 4), except for the pair of soils from Plot 15 in which this sum is the same and $\mathrm{Al}_{\mathrm{x}}$ in the organic layer is more than predicted by the $\mathrm{Al}_{\mathrm{x}}: \mathrm{pH}$ relationship (Fig. 2). The sum of basic cations



FIG. 4. The effect of soil $\mathrm{pH}$ on the sum of exchangeable $\mathrm{Na}, \mathrm{K}, \mathrm{Mg}$, and $\mathrm{Ca}$ (me $\mathrm{kg}^{-1}$ ) in $1 \mathrm{M} \mathrm{NH}_{4} \mathrm{NO}_{3}$ for 'organic'- and 'mineral'-rich layers. 
in both layers of the only limed acid soil $(11 \mathrm{~L} / \mathrm{O}: \mathrm{pH} 3.54$ and $11 \mathrm{~L}: \mathrm{pH}$ 3.38 ) is much greater than predicted by the curve for the unlimed soils (Fig. 4) demonstrating the accumulation of exchangeable $\mathrm{Ca}$ residues even at such low $\mathrm{pH}$ values, and suggesting that the $\Sigma(\mathrm{Na}+\mathrm{K}+\mathrm{Mg}+\mathrm{Ca}): \mathrm{pH}$ relationship for limed acid soils would be different than for unlimed acid soils.

The number of $\mathrm{Mg}+\mathrm{Ca}$ atoms released per atom of $\mathrm{C}$ is always less in the organic- than in the mineral-rich layer of the soils. This difference between the mineral and organic layers is defined here by

$$
\Delta\left[\frac{\mathrm{Mg}_{\mathrm{x}}+\mathrm{Ca}}{\mathrm{C}}\right]=\left[\frac{\mathrm{Mg}_{\mathrm{x}}+\mathrm{Ca}_{\mathrm{x}}}{\mathrm{C}}\right]_{\text {mineral }}-\left[\frac{\mathrm{Mg}_{\mathrm{x}}+\mathrm{Ca}_{\mathrm{x}}}{\mathrm{C}}\right]_{\text {organic }}
$$

where atom ratios are used throughout. The corresponding symbol for exchangeable $\mathrm{Al}$ is $\Delta\left(\mathrm{Al}_{\mathbf{x}} / \mathrm{C}\right)$. The value of $\Delta\left[\left(\mathrm{Mg}_{\mathrm{x}}+\mathrm{Ca} \mathrm{a}_{\mathrm{x}}\right) / \mathrm{C}\right]$ is always positive, even at $\mathrm{pH}$ values as low as 2.9 , suggesting that the upper organic-rich layer is less active in such linkages than the lower mineral-rich layer.

$\Delta\left[\left(\mathrm{Mg}_{\mathrm{x}}+\mathrm{Ca}_{\mathrm{x}}\right) / \mathrm{C}\right]$ increases with soil $\mathrm{pH}$ (Fig. 5) indicating that the organic matter accumulating progressively in the lower layers is more active in this respect at higher pHs. Also $\Delta\left[\left(\mathrm{Mg}_{\mathrm{x}}+\mathrm{Ca}_{\mathrm{x}}\right) / \mathrm{C}\right]$ is inversely related to $\Delta\left[\mathrm{Al}_{\mathrm{x}} / \mathrm{C}\right]$ (Fig. 6), reflecting the changeover in the chelating



FIG. 5. The effect of soil $\mathrm{pH}$ on $\Delta\left[\left(\mathrm{Mg}_{\mathrm{x}}+\mathrm{Ca}_{\mathrm{x}}\right) / \mathrm{C}\right]$. 


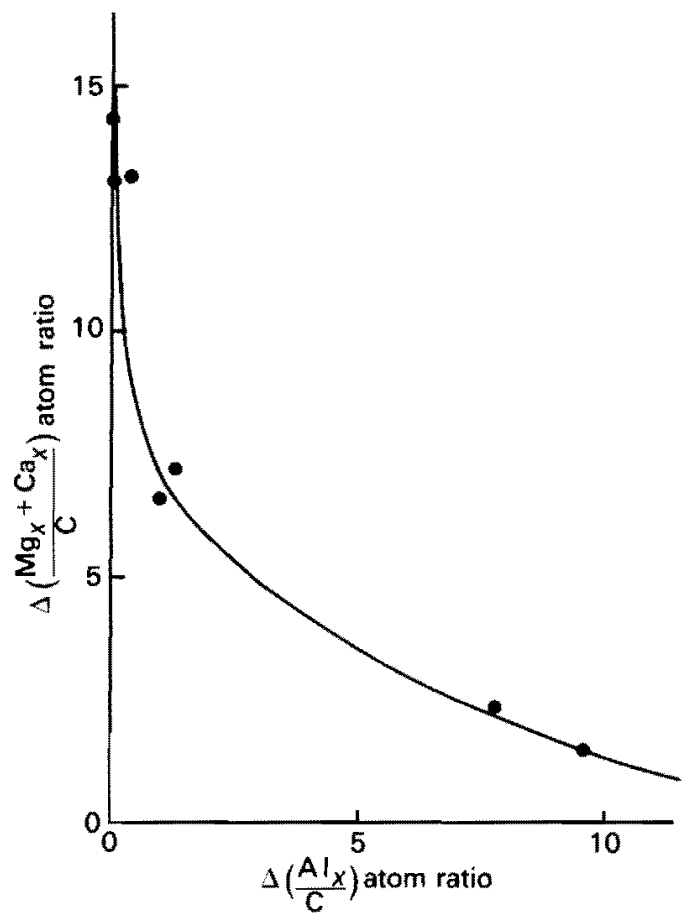

FIG. 6. Relationship between $\Delta\left[\left(\mathrm{Mg}_{\mathrm{x}}+\mathrm{Ca}_{\mathrm{x}}\right) / \mathrm{C}\right]$ and $\Delta\left[\mathrm{Al}_{\mathbf{x}} / \mathrm{C}\right]$ for some acid Park Grass soils.

activity of soil organic matter for $\mathrm{Al}$ to $(\mathrm{Mg}+\mathrm{Ca})$ as soil $\mathrm{pH}$ increases, the point of inflexion being at about 3.9 .

Rate of extraction of exchangeable $A l\left(A l_{x}\right)$ )

The relationship between Al-extracted and time represents the sum of the processes of extraction of $\mathrm{Al}_{\mathrm{n} x}$ and $\mathrm{Al}_{\mathrm{x}}$. This curve becomes linear after $24 \mathrm{~h}$ and the slope of the linear part is the constant rate of $\mathrm{Al}_{\mathrm{n} x}$ extraction. Subtracting $\mathrm{Al}_{\mathrm{n} x}$ at each time from the total $\mathrm{Al}$ extracted gives the progressive rate of extraction of $\mathrm{Al}_{\mathrm{x}}$ which slows to zero after $24 \mathrm{~h}$ (Sivasubramaniam and Talibudeen, 1972). The $\mathrm{NH}_{4}^{+}$ concentration in the influent solution is in considerable excess, hence the rate at which $\mathrm{Al}_{\mathrm{x}}$ is extracted can be considered proportional to the concentration of $\mathrm{Al}$ on exchange sites and be expressed by a first order kinetic equation:

$$
\frac{d\left(\mathrm{Al}_{t} / \mathrm{Al}_{0}\right)}{d t}=-k_{\mathrm{x}} \mathrm{Al}_{t}
$$

where $\mathrm{Al}_{0}$ and $\mathrm{Al}_{\mathrm{t}}$ are the amounts of $\mathrm{Al}$ on exchange sites at zero time and at time $t$ of extraction respectively, and $k_{x}$ is the absolute velocity 
constant of the reaction. Integrating equation (1) with the boundary conditions,

$$
t=0 \frac{\mathrm{Al}_{t}}{\mathrm{Al}_{0}}=1 ; t=\infty \frac{\mathrm{Al}_{t}}{\mathrm{Al}_{0}}=0, \text { gives } \ln \left(\frac{\mathrm{Al}_{t}}{\mathrm{Al}_{0}}\right)=-k_{x} t
$$

If the rate of release of $\mathrm{Al}_{\mathrm{x}}$ follows this equation, the relationship between $\ln \left(\mathrm{Al}_{t} / \mathrm{Al}_{0}\right)$ and $t$ should be linear, with the negative regression coefficient, $k_{\mathrm{x}}$, as the rate constant. Values of $k_{\mathrm{x}}$ obtained in this way were very similar for all the soils. In four soils $k_{\mathrm{x}}$ values were identical for the organic- and mineral-layers. This indicates that $\mathrm{Al}_{\mathbf{x}}$ in both organic- and mineral-layers is released from surfaces with similar properties for the adsorption of $\mathrm{Al}$ which are not affected by the nature of the adsorbed organic matter. Thus soil $\mathrm{pH}$ and organic matter did not affect the rate constant for the release of $\mathrm{Al}_{\mathrm{x}}$ significantly, the mean value for the 14 soils being $36 \pm 7 \times 10^{-6} \mathrm{~s}^{-1}$.

\section{Rate of extraction of non-exchangeable $A l\left(A l_{n x}\right)$}

Figure 7 shows that the relationship between the rate of $\mathrm{Al}_{\mathrm{nx}}$ extraction $d\left(\mathrm{Al}_{\mathrm{n} \times}\right) / d t$ (Table 2 ), and soil $\mathrm{pH}$ for organic- and minerallayers is indentical, exhibiting a maximum at about $\mathrm{pH}$ 3.7. Such a maximum was also observed by Pionke and Corey (1967) for $\mathrm{Al}_{\mathrm{nx}}$, calculated from the difference between $\mathrm{Al}$ extracted with $1 \mathrm{M} \mathrm{NH} \mathrm{NH}_{4} \mathrm{OAc}$ at $\mathrm{pH} 4.8$ and with $1 \mathrm{M} \mathrm{KCl}$. They suggested that this maximum was caused by the tendency of $\mathrm{Al}_{\mathrm{n} x}$ to change to $\mathrm{Al}_{\mathrm{x}}$ at low $\mathrm{pHs}$ and for both kinds of $\mathrm{Al}$ to change eventually into $\mathrm{Al}(\mathrm{OH})_{3}$ at high $\mathrm{pH}$ values. The $\mathrm{Al}_{\mathrm{n} x}$ extracted using $1 \mathrm{M} \mathrm{NH} \mathrm{NH}_{4} \mathrm{OAc}$ is largely that complexed by soil organic matter (cf. Sivasubramaniam and Talibudeen, 1972). The maximum observed at $\mathrm{pH} 3.7$ suggests that at lower $\mathrm{pH}$ values, the organic matter- $\mathrm{Al}_{\mathrm{n} x}$ complex becomes increasingly unstable.

However, most of the $\mathrm{Al}_{n x}$ extracted with $1 \mathrm{M} \mathrm{NH}_{4} \mathrm{NO}_{3}$ dissolves from the edge faces (constituting $<20$ per cent of the total surface area) of micaceous and kaolinitic minerals, as well as from hydrous oxides of $\mathrm{Al}$ in acid soils and hydrolysed interlayers in soil micas. The positive charge on these surfaces increases with decreasing $\mathrm{pH}$ and probably holds anionic groups on soil organic matter by coulombic attraction causing its reactive fraction to cover these surfaces uniformly. Similarly, proton-accepting groups (e.g. amino- and amido-groups) participating in proton-bridging between such groups and the $\left(-\mathrm{Al}=\mathrm{O}_{\mathrm{H}}\right)$ sites at these octahedral edge faces could contribute also to a protective film. These factors probably contribute to the observation that $\mathrm{Al}_{\mathrm{n}}$ from clay minerals extracted by $1 \mathrm{M} \quad \mathrm{NH}_{4} \mathrm{NO}_{3}$ decreases with decreasing $\mathrm{pH}$. At $\mathrm{pH}>3.7$, however, hydrated aluminium oxides $\left(\mathrm{Al}_{2} \mathrm{O}_{3} \cdot \mathrm{nH}_{2} \mathrm{O}\right)$ are precipitated increasingly, causing a maximum to be obtained at this $\mathrm{pH}$. 


\section{Acknowledgements}

F. Cabrera thanks the Ramsay Memorial Fellowships Trust for financial support. V. Cosimini provided $\mathrm{Na}, \mathrm{K}, \mathrm{Mg}$, and $\mathrm{Ca}$ analyses and Mrs. I. Jasko the organic carbon analyses.

\section{REFERENCES}

CHENERY, E.M. 1948. Thioglycollic acid as an inhibitor for iron in the colorimetric determination of aluminium by means of "Aluminon". Analyst, Lond. 73, 501-3.

COLEMAN, N. T., and THOMAS, G.W. 1967. In Soil acidity and liming. (ed. R. W. Pearson and F. Adams), The basic chemistry of soil acidity, pp. 1-41. Am. Soc. Agron. Monog. No. 9, Madison, Wisconsin.

EVANS, C. E., and KAMPRATH, E. J. 1970. Lime response as related to percent Al saturation, solution Al, and organic matter content. Proc. Soil Sci. Soc. Am. 34, 893-6.

HOYT, P.B., and TURNER, R. C. 1975. Effects of organic materials added to very acid soils on $\mathrm{pH}$, aluminium, exchangeable $\mathrm{NH}_{4}$, and crop yields. Soil Sci. 119, 227-37.

LIM, T. S., and TALIBUDEEN, O. 1975. The behaviour of exchangeable aluminium in acid soils. Rothamsted Expl. Sta. Rep. 1974, Part 1, 87.

McLEAN, E. O., REICOSKY, D. C., and LAKSHMANAN, C. 1965. Aluminium in soils: 7. Inter relationships of organic matter, liming, and extractable aluminium with "permanent charge' $(\mathrm{KCl})$ and $\mathrm{pH}$-dependent cation exchange capacity of surface soils. Proc. Soil Sci. Soc. Am. $29,374-8$.

PIONKE, H. B., and COREY, R. B. 1967. Relations between acidic aluminium and soil pH, clay and organic matter. Ibid. 31, 749-52.

PYMAN, M. A. F., POSNER, A. M, and TALIBUDEEN, O. 1976. Hydrolysed aluminium ions on montmor illonite. Rothamsted Expl. Sta. Rep. 1975, Part I 94-5.

REEVE, N.G., and SUMNER, M.E. 1971. Cation exchange capacity and exchangeable aluminium in Natal Oxisols. Proc. Soil Sci. Soc. Am. 35, 38-42.

SILVA RODRIGUEZ, A., and SCHAEFER, R. 1971. Interacción entre materia orgánica $y$ aluminio en un suelo hidromórfico derivado de cenizas volcánicas (Nadi, Sur de Chile). Turrialba, $21,149-56$.

SIVASUBRAMANIAM, S., and TALIBUDEEN, O. 1972. Potassium-aluminium exchange in acid soils. I. Kinetics. J. Soil Sci. 23, 163-76.

SKEEN, J. B., and SUMNER, M.E. 1967 Exchangeable aluminium. Part 1. The efficiency of various electrolytes for extracting Al from acid soils. S. Afr. J. agric. Sci. 10, 3-10.

THOMAS, G.W. 1975. The relationship between organic matter content and exchangeable aluminium in acid soils. Proc. Soil Sci. Soc. Am. 39, 591.

WARREN, R. G., and JOHNSTON, A. E. 1964. The Park Grass Experiment. Rothamsted Expl. Sta. Rep. 1963, pp. 240-262. 